Laidlaw, K., Broadbent. E., \& Eby, S. (2021). Effectiveness of aerial wildlife crossings: Do wildlife use rope bridges more than hazardous structures to cross roads?. Revista de Biología Tropical, 69(3), 1138-1148. https://doi org/10.15517/rbt.v69i3.47098

\title{
Effectiveness of aerial wildlife crossings: Do wildlife use rope bridges more than hazardous structures to cross roads?
}

Katra Laidlaw ${ }^{1 *}$; (D) https://orcid.org/0000-0002-7782-1339

Eben Broadbent ${ }^{2}$; (D) https://orcid.org/0000-0002-4488-4237

Stephanie Eby33 (D) https://orcid.org/0000-0001-7047-7101

1. Department of Marine and Environmental Sciences, Northeastern University, 02115, Boston, Massachusetts, United States of America; katra.laidlaw@gmail.com (Correspondence*)

2. School of Forest, Fisheries, and Geomatics Sciences, University of Florida, 32611, Gainsville, Florida, United States of America; eben@ufl.edu

3. Department of Marine and Environmental Sciences, Northeastern University, 02115, Boston, Massachusetts, United States of America; s.eby@northeastern.edu

Received 23-V-2021. Corrected 09-IX-2021. Accepted 30-IX-2021.

\begin{abstract}
Introduction: Although wildlife crossing structures have proven successful at reducing wildlife-vehicle collisions and linking fragmented habitat, their ability to prevent electrocutions of arboreal wildlife has not been closely examined.

Objective: To evaluate the effectiveness of aerial rope bridges in restoring habitat connectivity for arboreal species in Manuel Antonio, Costa Rica, while preventing electrocutions by determining 1) what species are using the rope bridges and 2) whether wildlife prefer to use rope bridges instead of other hazardous structures that cross the roads (such as telephone cables, which are often in close proximity to electric wires).

Methods: From January to May 2016, nine rope bridges along the highly-trafficked main road that extends from Quepos to Manuel Antonio, Costa Rica, were monitored using camera traps, and ten rope bridges were observed directly along a paved side road off the main road.

Results: A total of 11 species were seen using the bridges, and 1540 crossings were witnessed via camera traps and observations (1 234 via camera traps, 306 during observations). Results from a paired t-test showed no significant difference in the average number of individuals crossing the road via rope bridges versus telephone cables $(\mathrm{t}(8)=1.027, \mathrm{P}=0.334)$.

Conclusions: Rope bridges are used by a variety of arboreal wildlife species with a high degree of frequency; however, due to the equally high usage of telephone cables by arboreal wildlife, they are insufficient to prevent wildlife electrocutions on their own. Rope bridges should be installed in tandem with other methods to prevent electrocutions, such as insulating electric wires, to facilitate the safe passage of wildlife over roads.
\end{abstract}

Key words: electrocution mitigation; telephone cables; anthropogenic impacts; habitat modification; behavioral ecology; wildlife management; endangered species; Costa Rica.

Habitat loss and fragmentation lead to a variety of negative consequences for ecosystems (Broadbent et al., 2008; Chape et al., 2005; Haddad et al., 2015). Long-term studies have indicated that habitat fragmentation degrades ecosystems, reduces species richness and persistence, impedes nutrient retention, alters trophic dynamics, and hinders 
wildlife movement among isolated habitat fragments (Haddad et al., 2015; Turner, 1996). Roads are one of the main causes of habitat fragmentation (Coffin, 2007; Spellerberg, 1998; van der Ree et al., 2011).

In addition to fragmenting habitats, roads also cause the death of wildlife due to collisions with vehicles (Artavia, 2015; Caceres, 2011; Coffin, 2007; Laurance et al., 2009). Although arboreal species generally experience fewer vehicle-related deaths than terrestrial species, they still experience a significant amount of vehicular mortality (Artavia, 2015; Caceres, 2011; Rodrigues \& Martinez, 2014). Powerlines, which often run along roads, also kill wildlife, particularly arboreal wildlife, via electrocutions (Cunneyworth \& Slade, 2021; Kumar \& Kumar, 2015; Lindshield, 2016; Lokschin et al., 2007; Moore et al., 2010; Rodrigues \& Martinez, 2014; Teixeira et al., 2013). For example, in Ilhéus, Bahia, Brazil, electrocutions are the leading cause of injury and/or death of Wied's Marmosets (Callithrix kuhlii) due to human infrastructure (Rodrigues \& Martinez, 2014).

If wildlife is unable to safely access habitat on the other side of the road, then roads eventually lead to the genetic isolation of wildlife populations, thereby increasing the risk of inbreeding and local species extinctions (Caceres, 2011; Forman et al., 2003; Glista et al., 2009; Haddad et al., 2015; Rybicki \& Hanski, 2013). Local extinctions could cause changes in community structure, which may ultimately lead to further extinctions (Larsen et al., 2005). This would be especially true if the species that go locally extinct are important pollinators or seed dispersers (Anderson et al., 2011; Memmott et al., 2004; Van Wieren \& Worm, 2001). Many types of arboreal rainforest wildlife, such as primates, play an important role in the seed dispersal of rainforest plants (Bond, 1994; Chapman \& Russo, 2005). If seed-dispersing wildlife becomes locally extinct, then plants that have developed reproductive dependence on this mutualism could also become extinct (Memmott et al., 2004). This would decrease plant diversity and regeneration in the rainforest, which may, in turn, negatively impact other wildlife species (Bond, 1994; Cordeiro \& Howe, 2003).

To reduce road-related deaths of wildlife and mitigate the effects of habitat fragmentation, a variety of approaches have been used. These approaches generally aim to modify the behavior of motorists and/or to modify the behavior of wildlife. To change the behavior of motorists, speed limits, lights, and signs have been established to warn drivers of the presence of crossing wildlife (Forman et al., 2003). To change the behavior of wildlife, crossing structures and habitat modifications have been implemented (Glista et al., 2009). Although the effectiveness of wildlife crossing signs is questionable, wildlife-crossing structures have proven successful at reducing roadkill and restoring habitat connectivity (Dodd et al., 2004; Glista et al., 2009; Van Wieren \& Worm, 2001).

Rope bridges have been shown to be effective wildlife crossing structures for a variety of arboreal species (e.g., Lindshield, 2016; Lokschin et al., 2007; Teixeira et al., 2013; Weston \& Goosem, 2011). However, despite their usage, wildlife also attempts to cross roads using telephone cables and electric wires (Lokschin et al., 2007; Teixeira et al., 2013). Although telephone cables do not directly pose a threat to wildlife, they are usually connected to the same poles as electric wires and, therefore, can inadvertently bring wildlife in close proximity to dangerous structures such as uncovered electric wires and transformers. When wildlife uses telephone cables to cross the road, they are at a higher risk of electrocution than if they choose to cross the road on rope bridges, which are not connected to the electric poles.

This study aims to evaluate the effectiveness of rope bridges in reconnecting fragmented habitats while preventing the electrocution of arboreal wildlife. Specifically, this study aims to determine what species of wildlife are using the rope bridges in the Quepos/Manuel Antonio area of Costa Rica, how frequently they use the rope bridges, and whether they use the bridges 
more than hazardous structures (such as telephone cables that are adjacent to electric wires) to cross roads. Although other studies have noted the use of telephone cables by arboreal wildlife (Lokschin et al., 2007; Moore et al., 2010; Rodrigues \& Martinez, 2014), this is the first study to quantitatively compare the usage of telephone cables by wildlife with the usage of crossing structures intentionally installed for wildlife (i.e., rope bridges). We hypothesize that arboreal wildlife will use rope bridges more than telephone cables or electric wires to cross the road due to frequent sightings of wildlife using rope bridges by local residents. We tested this hypothesis by conducting daily observations at a series of ten rope bridges along a road with telephone cables and uncovered electric wires and installing camera traps on an additional nine rope bridges distributed throughout the study area.

\section{MATERIALS AND METHODS}

Study site: The study area is located South of Quepos and North of Manuel Antonio, Costa Rica (9²5'55.2"'-9॰23'33.3" N \& 8409'41.6$\left.84^{\circ} 08^{\prime} 13.2^{\prime \prime} \mathrm{W}\right)$. Costa Rica is an ideal location to conduct this study because electrocutions from power lines and transformers and vehicular mortalities are the primary causes of death for wildlife in the country (Lindshield, 2016; Monge-Nájera, 2018). The study was conducted in a mixed-use area that consists primarily of hotels and restaurants with some residential housing (Fig. 1). Extending from Quepos to Manuel Antonio, there is a highly-trafficked two-lane road (approximately $6 \mathrm{~m}$ wide) that is frequented by charter bus companies, taxis, and local buses that run every $20 \mathrm{~min}$. Stemming from the main road are less trafficked roads, the majority of which are gravel. The speed limit

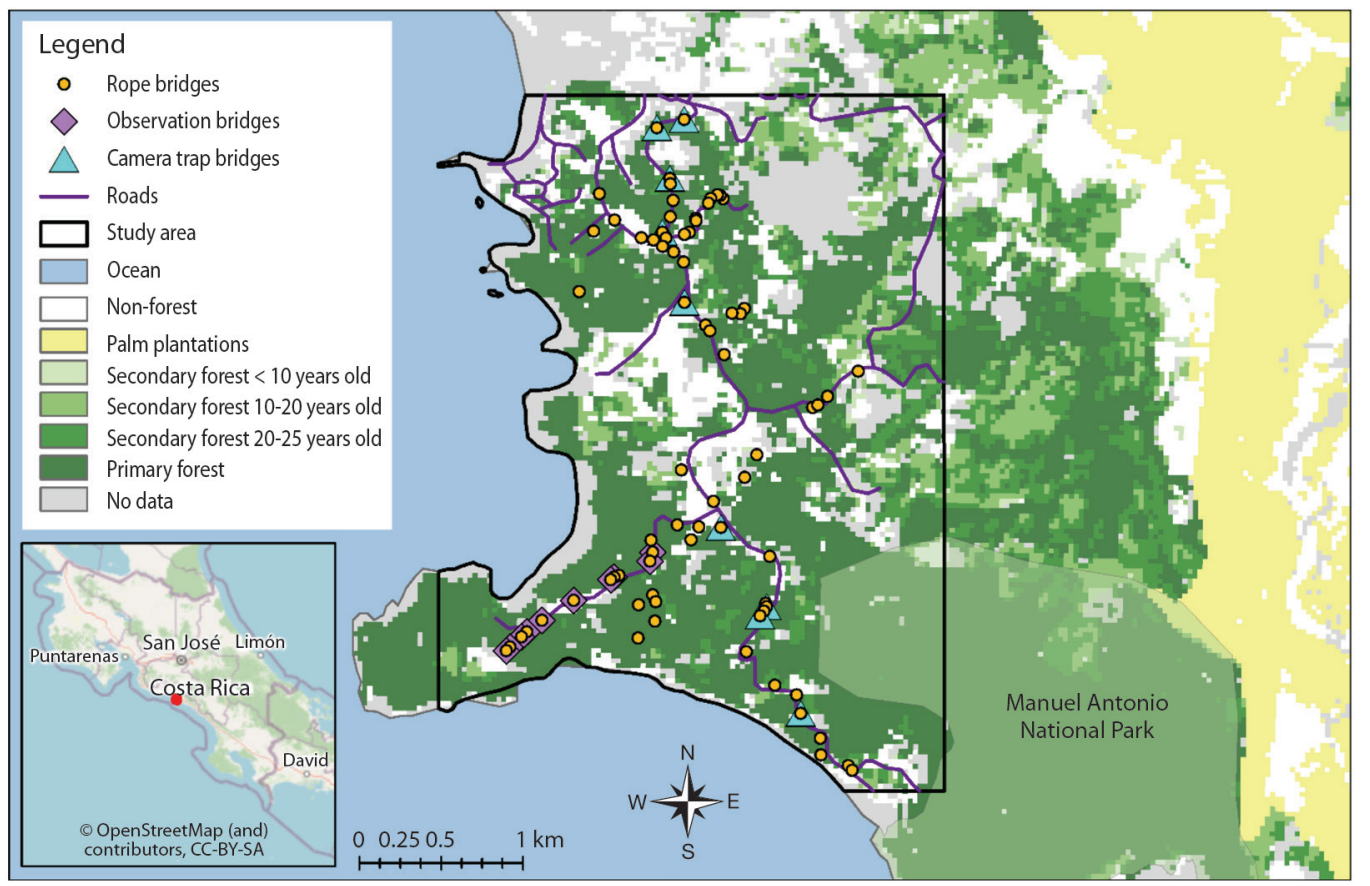

Fig. 1. Map of the study area in Costa Rica with vegetation types overlaid with the locations of rope bridges (vegetation data from Broadbent et al., 2012). 
for the main road is $40 \mathrm{kph}$, although vehicles regularly exceed this speed limit. Amidst the buildings and roads are patches of primary and secondary forest which are inhabited by a variety of wildlife.

Throughout the study area, 75 rope bridges for wildlife extend across the main and side roads, installed at an average distance of 90.48 $\mathrm{m}( \pm 8.56 \mathrm{SE})$ from one another. These bridges were installed by the wildlife rehabilitation center, Kids Saving the Rainforest, with the help of the local electric company, ICE, starting in 2000. The majority of the bridges were installed from 2001-2002. The wildlife bridges consist of a blue, $25 \mathrm{~mm}$, electricityproof, nylon rope that is fastened to trees on either side of the road, typically in the space between the electric wires and the telephone cables (Fig. 2).

Observations: Ten rope bridges were observed along a paved side road (approximately 5-6 m wide) off of the main road that runs between Quepos and Manuel Antonio (Fig. 1). At each bridge location, an average of three electric wires and six telephone cables crossed the road $(\leq 15 \mathrm{~m}$ from the rope bridge) (Fig. 2). This area was chosen because the electric wires along this road are not insulated; therefore, they pose an electrocution risk to wildlife.

Animal counts were conducted, from 7:009:00 a.m., and from 3:30-5:30 p.m., for a total of five morning and five afternoon sessions at each bridge location between 2/28/2016 and $5 / 13 / 2016$. During observation sessions, the observer sat in a folding chair at the side of the road a minimum of $5 \mathrm{~m}$ away from the rope bridge because, at this distance, wildlife did not hesitate to approach the observer. In fact, many times, the wildlife would climb on the telephone cables that extended above the observer's head. Moreover, since Manuel Antonio is a main tourist area, wildlife is accustomed to seeing people. During observation sessions, when and what types of wildlife were seen and how they crossed the road (i.e., on the ground, jumping across the canopy, using the rope bridge, using the electric wires, or using the telephone cables) was noted.

Camera traps: Camera traps were placed on nine bridges, all located in similar habitat (primary forest), along the main road that

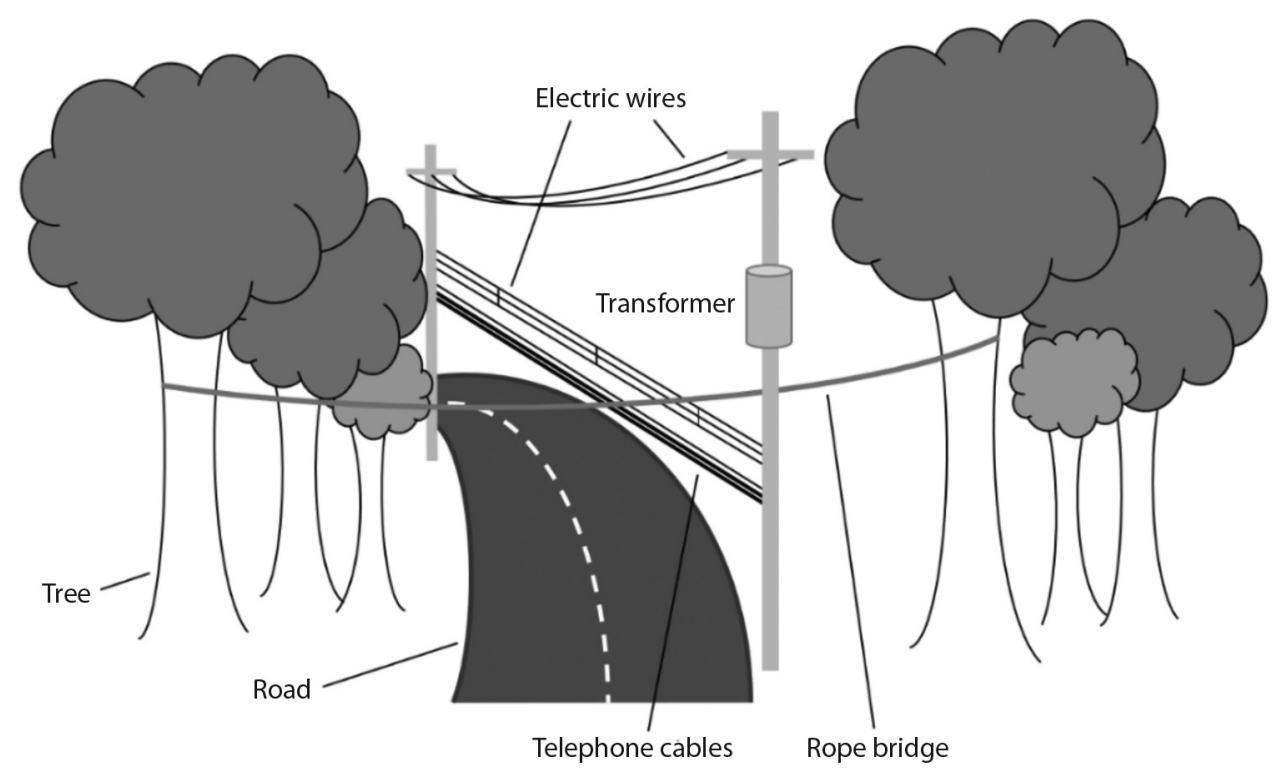

Fig. 2. Illustration of a typical rope bridge site with telephone cables and electric wires crossing the road within $\leq 15 \mathrm{~m}$ of the bridge. 
extends from Quepos to Manuel Antonio (Fig. 1). The main road was chosen because it is highly trafficked and therefore poses a high risk of fatal wildlife-vehicle collisions. At each of the bridge locations, there was an average of three electric wires and a cluster of six telephone cables that crossed the road $\leq 15 \mathrm{~m}$ from the rope bridge (Fig. 2).

PC800 Hyperfire Professional SemiCovert Camera traps were installed above the rope bridges with one RAM ${ }^{\circledR}$ Short Double Socket Arm (part number RAM-B-201U-A), and two RAM ${ }^{\circledR} 2.4 \mathrm{~cm}$ (1") balls (part number RAP-B-366U) connected to an $8.5 \times 19.5 \mathrm{~cm}$ portion of PVC pipe (with four slits carved for Nylon webbing straps). Prior to attaching the ball joints and double socket arm, the researcher painted the piece of PVC pipe brown and green using acrylic paint (to aid in camouflaging the camera). The first ball joint was connected to the piece of PVC by drilling a hole into the middle of the PVC and then securing it with a wing nut on the other side. The first ball joint was then connected to the double socket arm, and the second ball joint was connected to the opposite side of the double socket arm and then screwed into the back of the camera. Finally, the piece of PVC (with the double socket arm and ball joint attached to the camera) was secured to the tree using Nylon webbing straps and $2.4 \mathrm{~cm}(1$ ") plastic buckles that were threaded through the slits of the portion of PVC pipe (Gregory et al., 2014). Bicycle cables were threaded through the hole in the side of the cameras in order to discourage theft. In order to provide additional support, heavyduty $60 \mathrm{~cm}$ (24") cable ties were also threaded through the hole in the camera and secured to the tree using $1 \mathrm{~cm}(1 / 4$ ") fence staples at a 45-degree angle above the camera (Fig. 3).

The cameras were set to record $24 \mathrm{~h}$ a day, take three photographs per trigger, with one second between photographs and no 'quiet period' between triggers. The cameras were positioned about $30 \mathrm{~cm}$ or less above the rope bridge so that the photographs showed most of the bridge extending across the road. It was not always possible to capture the entirety of the bridge within the camera's frame because the passing cars would trigger the camera and

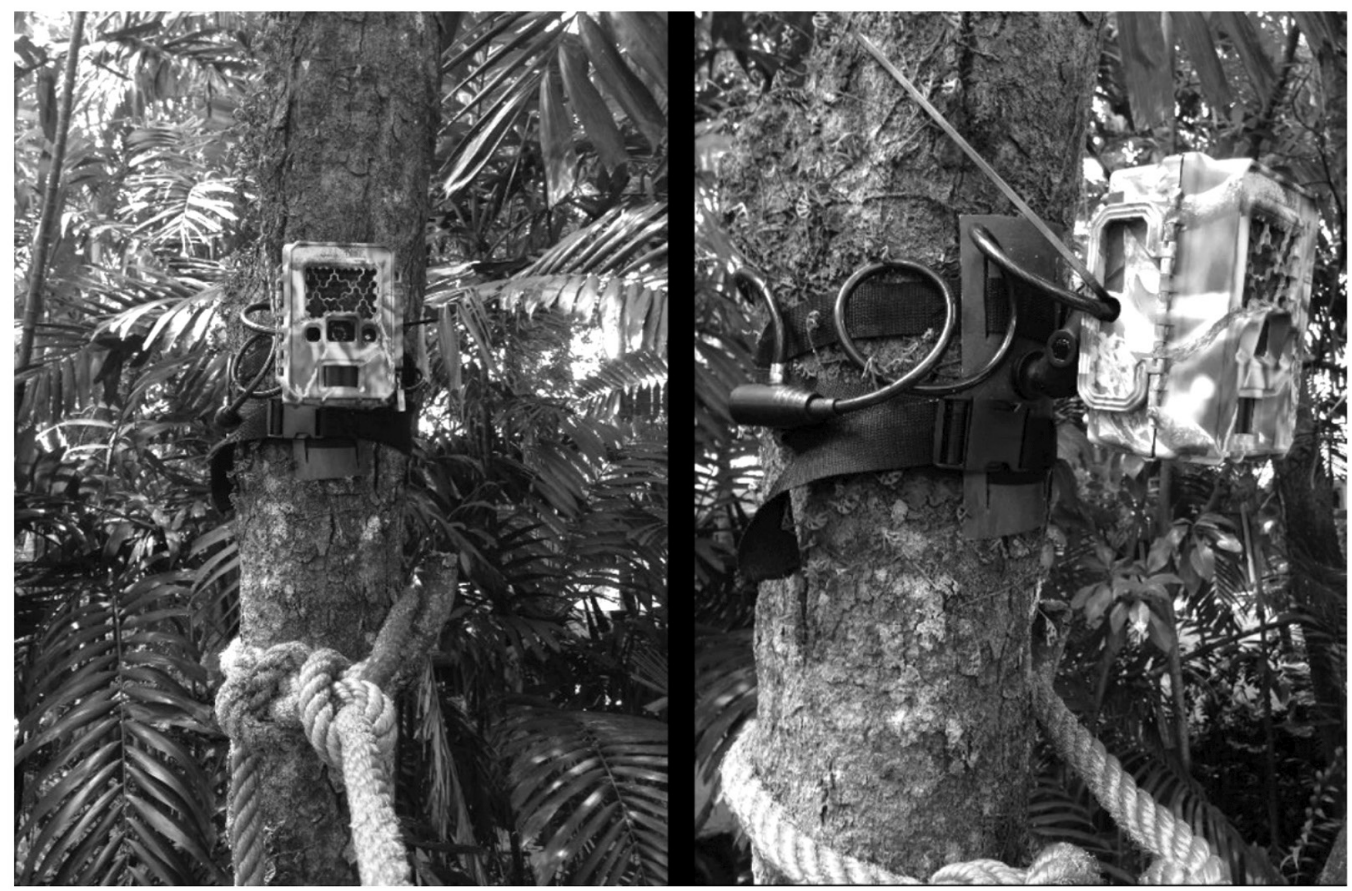

Fig. 3. Front and side view of the PC800 Hyperfire Professional Semi-Covert Camera trap mounted above a rope bridge. 
quickly cause the camera's SD card to fill up and the batteries to run out. Therefore, the length of the bridges that was not captured by the cameras ranged from 0.6 to $2.4 \mathrm{~m}$. Cameras were installed from $1 / 29 / 16$ to $5 / 21 / 16$ for an average of $459.49 \mathrm{~h}$ each $( \pm$ SE 80.21$)$.

Data analysis: For the observation data, a paired t-test was used to compare the average number of crossings that occurred via the rope bridges versus the telephone cables. All statistics were conducted in Microsoft Excel ${ }^{\circledR}$.

\section{RESULTS}

A total of 11 species were seen using the bridges, and 1540 crossings were witnessed via camera traps and observations (1 234 via camera traps, 306 during observations) (Table 1). An average of 8.44 ( \pm SE 3.69) crossings per bridge were captured by the camera traps per day, and an average of 6.12 ( \pm SE 3.77) crossings per bridge were seen during observations per day. The following species were seen: common opossum (Didelphis marsupialis); Derby's woolly opossum (Caluromys derbianus); kinkajou (Potos flavus); Mexican tree porcupine (Coendou mexicanus); two-fingered sloth (Choloepus hoffmanni); Northern tamandua (Tamandua mexicana); white-faced monkey (Cebus capucinus); grey-crowned Central American squirrel monkey (Saimiri oerstedii citrinellus); mantled howler monkey (Alouatta palliata); three-fingered sloth (Bradypus variegatus); and variegated squirrel (Sciurus variegatoides) (Table 1).

During observations only one squirrel monkey (Saimiri oerstedii citrinellus) was seen using an electric wire to get across the road. Therefore, electric wires were excluded from all statistical analyses. Results from a paired t-test showed no significant difference in the average number of crossings that occurred via rope bridges versus telephone cables $(\mathrm{t}(8)=$ 1.027, $\mathrm{P}=0.334$ ) (Fig. 4).

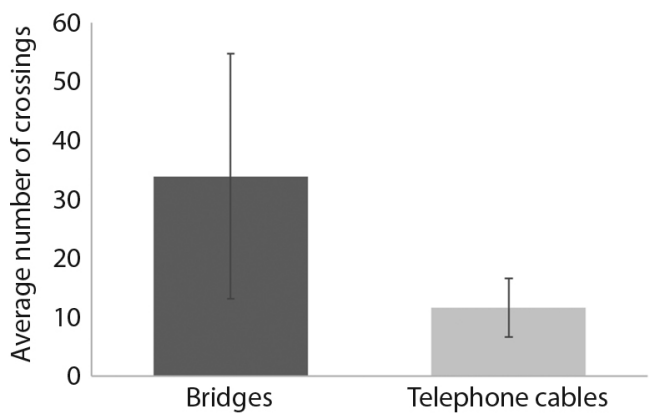

Fig. 4. There was no significant difference in the average number of road crossings $( \pm \mathrm{SE})$ that occurred via the bridges or telephone cables $(\overline{\mathrm{P}}=0.3)$.

TABLE 1

Total number of crossings of each species seen using bridges

\begin{tabular}{lcc}
\hline \multicolumn{1}{c}{$\begin{array}{c}\text { Species observed } \\
\text { using bridges }\end{array}$} & $\begin{array}{c}\text { Number of crossings seen } \\
\text { during observations }\end{array}$ & $\begin{array}{c}\text { Number of crossings seen } \\
\text { via camera traps }\end{array}$ \\
\hline Saimiri oerstedii citrinellus & 199 & 402 \\
Cebus capucinus & 65 & 337 \\
Alouatta palliata & 39 & 179 \\
Sciurus variegatoides & 2 & 79 \\
Bradypus variegatus & 1 & - \\
Potos flavus & - & 125 \\
Coendou mexicanus & - & 55 \\
Caluromys derbianus & - & 27 \\
Choleopus hoffmanni & - & 12 \\
Didelphis marsupialis & - & 9 \\
Tamandua mexicana & - & 9 \\
Total & 306 & 1234 \\
\hline
\end{tabular}




\section{DISCUSSION}

Wildlife crossing structures have proven successful at reducing roadkill and restoring habitat connectivity in a variety of contexts and are an essential tool in mitigating the negative effects of roads on wildlife (e.g., Dodd et al., 2004; Glista et al., 2009; Van Wieren \& Worm, 2001). However, the relationship between rope bridges and electrocutions has largely been unexamined. Over the course of this study, rope bridges in Manuel Antonio, Costa Rica, were frequently used by a variety of arboreal wildlife with average crossing frequencies comparable to the high usage of rope bridges by the endangered Western ringtail possums (Pseudocheirus occidentalis) in Australia (8.87 \pm 0.59 complete crossings per night) (Yokochi $\&$ Bencini, 2015). However, despite their high usage, there was not a significant difference in usage between the rope bridges and the telephone cables, which were in close proximity to uncovered electric wires. It seems that wildlife will use any infrastructure that allows them to move throughout the landscape.

Electrocution risk: Only one individual was seen crossing the road using an electric wire during observations of the ten rope bridges along the side road. However, local residents witnessed the electrocutions of two mantled howler monkeys and one grey-crowned Central American squirrel monkey, and we saw a dead two-fingered sloth showing signs of electrocution along that same road. It is possible that wildlife in the area does not typically choose electric wires to cross the road because they are thinner and therefore more difficult to walk across than the thicker clusters of telephone cables. Alternatively, it is possible that wildlife accustomed to using telephone cables may not perceive electric wires as a threat and may eventually get electrocuted when attempting to use them in the future (Lindshield, 2016).

These findings are consistent with the incidences of electrocutions of arboreal wildlife in other locations (Cunneyworth \& Slade, 2021; Kumar \& Kumar, 2015; Lindshield,
2016; Lokschin et al., 2007; Moore et al., 2010; Rodrigues \& Martinez, 2014; SaavedraRodríguez et al., 2013; Teixeira et al., 2013). According to a study conducted in the rural areas of the city of Cali, Colombia, over the course of 14 months, two electrocuted Derby's woolly opossums (Caluromys derbianus) and two gray-bellied night monkeys (Aotus lemurinus) were found dead on the electric wires (Saavedra-Rodríguez et al., 2013). Given the substantially smaller area evaluated in this study, the three electrocutions that were witnessed firsthand along the same road, over the course of five months, constitutes a notably high rate of electrocutions.

Use of telephone cables: The lack of difference between rope bridge and telephone cable usage may indicate that arboreal species do not have a preference for the type of crossing structure and simply seek to cross the road however possible. In addition to witnessing wildlife using telephone cables to cross the roads, we also witnessed wildlife using telephone cables to travel alongside the road to gain access to the rope bridges. This could be problematic in cases where using the telephone cables puts the individual at a higher risk of electrocution by bringing them in close proximity to uncovered electric wires and transformers. On the other hand, if electrocution risk is low, for example, because the electric wires are covered, telephone cables might actually benefit arboreal species by providing safe passage away from traffic and other threats on the ground. However, ideally, canopy bridges should be installed above the powerlines with sufficient distance between them to prevent the electrocution of wildlife.

Alternatively, it could be that the lack of a difference in use has to do with site-specific factors. On average, there were more crossings via the bridges $(34 \pm 21)$ than the telephone cables $(12 \pm 5)$. However, there was large variability in site-specific bridge use with use ranging from $0-183$ crossings at a specific bridge site. This variability was also observed in preference between crossing structures at 
the site level. At five of the observation sites, wildlife used bridges more than the telephone cables. While at four of the sites, wildlife used the telephone cables more than bridges. Future studies should focus on trying to determine how use varies depending on site characteristics. Furthermore, how species-specific preferences affect the frequency of rope bridge use should also be evaluated in future studies. For example, Northern tamanduas (Tamandua mexicana) and common opossums (Didelphis marsupialis) are the species most frequently hit by cars in Costa Rica (Monge-Nájera, 2018). The degree of arboreality varies widely among Tamandua mexicana, and therefore, to effectively prevent road-related deaths of Northern tamanduas, terrestrial and arboreal crossing structures should be installed and monitored (Brown, 2011).

Other electrocution mitigation methods: Nevertheless, the fact that our data suggests that wildlife do not appear to prefer rope bridges over the telephone cables is a noteworthy finding. If wildlife does not prefer the bridges over the telephone cables, then rope bridges are insufficient to prevent wildlife electrocutions on their own. This suggests that other methods, aside from installing rope bridges, need to be employed in order to prevent wildlife electrocutions. Unfortunately, according to ICE, the costs of insulating powerlines are substantial; it would cost $\$ 250$ to insulate a transformer, $\$ 18462$ to insulate a $\mathrm{km}$ of secondary electric wires, \$ $21538-\$ 46154$ to insulate a $\mathrm{km}$ of semi-isolated electric wires, and \$ 141129 to bury a $\mathrm{km}$ of electric wires. Therefore, further studies should focus on assessing the success and cost-effectiveness of less expensive methods to prevent electrocutions, such as trimming branches that touch powerlines while maintaining natural canopy crossings and installing structures that successfully deter wildlife from accessing the electric wires. In Diani, Kenya, a combination of short-term and long-term solutions were implemented to prevent wildlife electrocutions, from trimming trees to relocating transformers and isolating electric cables, and despite the expansion of electricity infrastructure throughout the study period, primate electrocutions did not increase (Cunneyworth $\&$ Slade, 2021). If less expensive methods do not prove sufficient or cost-effective in the long term, covering the wires in locations with high amounts of electrocutions may be the only viable permanent solution. There is evidence, in some localities, that electrocutions occur in hotspots, meaning that the strategic insulation of these zones could greatly reduce the number of electrocutions overall (Katsis et al., 2018; Ram et al., 2015).

Conclusion: Where electric wires are covered, telephone cables provide a relatively safe way for wildlife to cross the roads and navigate modified habitats. However, in areas where electric wires are uncovered, rope bridges should be installed along with other electrocution mitigation methods, such as insulating the electric wires, to effectively facilitate the safe passage of wildlife across roads while preventing wildlife electrocutions. Further research is needed to determine the most cost-effective combination of strategies to mitigate arboreal wildlife electrocutions while taking into account the site-specific conditions and species-specific preferences. Additional studies are also needed in the Manuel Antonio area to determine the effect of the rope bridges in maintaining the genetic diversity of local populations of wildlife, particularly the endangered grey-crowned Central American squirrel monkey.

Ethical statement: the authors declare that they all agree with this publication and made significant contributions; that there is no conflict of interest of any kind; and that we followed all pertinent ethical and legal procedures and requirements. All financial sources are fully and clearly stated in the acknowledgements section. A signed document has been filed in the journal archives. 


\section{ACKNOWLEDGMENTS}

First and foremost, we would like to thank Rocío Pérez for her unyielding support and incredibly useful knowledge of the rope bridges and their history. Additionally, we would like to thank Grupo ICE (specifically José Ricardo Carvajal Rodríguez) for supporting this project by helping to install the camera traps and maintaining the rope bridges. We would also like to thank, Kids Saving the Rainforest, for establishing the Monkey Bridge Project and for helping to facilitate this project. We would also like to express our gratitude to Tremaine Gregory, for helping to troubleshoot during the installation of the camera traps and assisting during the launching of the study. Thank you to Northeastern University for providing scholarship funding to pay for supplies and living costs.

\section{RESUMEN}

\section{Eficacia de los pasos aéreos sobre carretera: ¿Cruza la fauna más por puentes de cuerda que por otras estructuras peligrosas?}

Introducción: Aunque los pasos de fauna han demostrado ser exitosos para reducir las colisiones entre vehículos y vida silvestre y vincular el hábitat fragmentado, su capacidad para prevenir electrocuciones de la vida silvestre arbórea no se ha examinado a fondo.

Objetivo: Evaluar la efectividad de los puentes aéreos de cuerdas para restaurar la conectividad del hábitat de las especies arbóreas en Manuel Antonio, Costa Rica y al mismo tiempo prevenir las electrocuciones al determinar 1) qué especies están usando los puentes de cuerda y 2) si la vida silvestre prefiere usar puentes de cuerda en lugar de otras estructuras peligrosas que cruzan las carreteras (como cables telefónicos, que frecuentemente están muy cerca de cables eléctricos).

Métodos: De enero a mayo de 2016, se monitorearon nueve puentes de cuerda a lo largo de la carretera principal altamente transitada que se extiende desde Quepos a Manuel Antonio, Costa Rica, utilizando cámaras trampa y la observación directa en diez puentes de cuerda a lo largo de una carretera pavimentada más pequeña fuera de la carretera principal.

Resultados: Se observaron un total de 11 especies utilizando los puentes y se presenciaron 1540 cruces mediante cámaras trampa y observaciones (1 234 mediante cámaras trampa, 306 durante las observaciones). Los resultados de una prueba $\mathrm{t}$ pareada no mostraron diferencias significativas en el número promedio de individuos que cruzan la carretera a través de puentes de cuerda versus cables telefónicos, $\mathrm{t}(8)=1.027, \mathrm{P}=0.334$.

Conclusiones: Los puentes de cuerdas son utilizados por una variedad de especies de vida silvestre arbóreas con un alto grado de frecuencia; sin embargo, debido al uso igualmente elevado de cables telefónicos por parte de la vida silvestre arbórea, se considera que son insuficientes para prevenir las electrocuciones de la vida silvestre por sí solas. Los puentes de cuerda deben instalarse junto con otros métodos para evitar electrocuciones, como cables eléctricos aislados, para facilitar el paso seguro de la vida silvestre por las carreteras.

Palabras clave: mitigación de electrocuciones; cables telefónicos; impactos antropogénicos; modificación del hábitat; ecología del comportamiento; manejo de vida silvestre; especies en peligro de extinción; Costa Rica.

\section{REFERENCES}

Anderson, S. H., Kelly, D., Ladley, J. J., Molloy, S., \& Terry, J. (2011). Cascading effects of bird functional extinction reduce pollination and plant density. Science, 331(6020), 1068-1071. https://doi.org/10.1126/ science. 1199092

Artavia, A. (2015). Identificación y caracterización de cruces de fauna silvestre en la sección de la ampliación de la carretera nacional Ruta 32, Limón, Costa Rica (Master's Thesis). Centro Agronómico Tropical de Investigación y Enseñanza (CATIE), Costa Rica. http://repositorio.bibliotecaorton.catie.ac.cr/ handle/11554/7083

Bond, W. J. (1994). Do mutualisms matter? Assessing the impact of pollinator and disperser disruption on plant extinction. Philosophical Transactions of The Royal Society Series B: Biological Sciences, 334(1307), 83-90. https://doi.org/10.1098/rstb.1994.0055

Broadbent, E. N., Asner, G. P., Keller, M., Knapp, D. E., Oliveira, P. J. C., \& Silva, J. N. (2008) Forest fragmentation and edge effects from deforestation and selective logging in the Brazilian Amazon. Biological Conservation, 141(7), 1745-1757. https://doi. org/10.1016/j.biocon.2008.04.024

Broadbent, E. N., Almeyda Zambrano, A. M., Dirzo, R., Durham, W. H., Driscoll, L., Gallagher, P., Salters, R., Schultz, J., Colmenares, A., \& Randolph, S. G. (2012). The effect of land use change and ecotourism on biodiversity: a case study of Manuel Antonio, Costa Rica, from 1985 to 2008. Landscape Ecology, 27(5), 731-744. https://doi.org/10.1007/ s10980-012-9722-7

Brown, D. D. (2011). Activity patterns and space use of northern tamandua anteaters (Tamandua mexicana) on Barro Colorado Island, Panamá (Doctoral Dissertation). University of California Davis, USA. 
https://www.semanticscholar.org/paper/ActivityPatterns-and-Space-Use-of-Northern-on-Brown/ c8a33690a2385ff978b81d67c4dfd9b69c296e8a

Caceres, N. C. (2011). Biological characteristics influence mammal road kill in an Atlantic Forest-Cerrado interface in south-western Brazil. Italian Journal of Zoology, 78(3), 379-389. https://doi.org/10.1080/112 50003.2011.566226

Chape, S., Harrison, J., Spalding, M., \& Lysenko, I. (2005). Measuring the extent and effectiveness of protected areas as an indicator for meeting global biodiversity targets. Philosophical Transactions of The Royal Society Series B: Biological Sciences, 360(1454), 443-455. https://doi.org/10.1098/rstb.2004.1592

Chapman, C. A., \& Russo, S. E. (2005). Primate Seed Dispersal: Linking Behavioral Ecology with Forest Community Structure. In C. J. Campbell, A. F. Fuentes, K. C. MacKinnon, M. Panger, \& S. Bearder (Eds.), Primates in Perspective (pp. 510-525). Oxford University Press.

Coffin, A. W. (2007). From roadkill to road ecology: A review of the ecological effects of roads. Journal of Transport Geography, 15(5), 396-406. https://doi. org/10.1016/j.jtrangeo.2006.11.006

Cordeiro, N. J., \& Howe, H. F. (2003). Forest fragmentation severs mutualism between seed dispersers and an endemic African tree. Proceedings of the National Academy of Sciences, 100(24), 14052-14056. https:// doi.org/10.1073/pnas.2331023100

Cunneyworth, P. M. K., \& Slade, A. M. (2021). Impact of Electric Shock and Electrocution on Populations of Four Monkey Species in the Suburban Town of Diani, Kenya. International Journal of Primatology, 42, 171-186. https://doi.org/10.1007/ s10764-020-00194-z

Dodd, C. K., Barichivich, W. J., \& Smith, L. L. (2004). Effectiveness of a barrier wall and culverts in reducing wildlife mortality on a heavily traveled highway in Florida. Biological Conservation, 118(5), 619-631. https://doi.org/10.1016/j.biocon.2003.10.011

Forman, R. T. T., Sperling, D., Bissonette, J. A., Clevenger, A. P., Cutshall, C. D., Dale, V. H., Fahrig, L., France, R. L., Goldman, C. R., Heanue, K., Jones, J., Swanson, F., Turrentine, T., \& Winter, T. C. (2003). Road Ecology: Science and Solutions. Island Press.

Glista, D. J., DeVault, T. L., \& DeWoody, J. A. (2009). A review of mitigation measures for reducing wildlife mortality on roadways. Landscape and Urban Planning, 91(1), 1-7. https://doi.org/10.1016/j. landurbplan.2008.11.001

Gregory, T., Rueda, F. C., Deichmann, J., Kolowski, J., \& Alonso, A. (2014). Arboreal camera trapping: taking a proven method to new heights. Methods in
Ecology and Evolution, 5(5), 443-451. https://doi. org/10.1111/2041-210X.12177

Haddad, N. M., Brudvig, L. A., Clobert, J., Davies, K. F., Gonzalez, A., Holt, R. D., Lovejoy, T. E., Sexton, J. O., Austin, M. P., Collins, C. D., Cook, W. M., Damschen, E. I., Ewers, R. M., Foster, B. L., Jenkins, C. N., King, A. J., Laurance, W. F., Levey, D. J., Margules, C. R., ...Townshend, J. R. (2015). Habitat fragmentation and its lasting impact on Earth's ecosystems. Science Advances, 1(2), 1-9. https://doi. org/10.1126/sciadv. 1500052

Katsis, L., Cunneyworth, P. M. K., Turner, K. M. E., \& Presotto, A. (2018). Spatial Patterns of Primate Electrocutions in Diani, Kenya. International Journal of Primatology, 39, 493-510. https://doi.org/10.1007/ s10764-018-0046-6

Kumar, V., \& Kumar, V. (2015). Seasonal electrocution fatalities in free-range rhesus macaques (Macaca mulatta) of Shivalik hills area in northern India. Journal of Medical Primatology, 44(3), 137-142. https:// doi.org/10.1111/jmp.12168

Larsen, T. H., Williams, N. M., \& Kremen, C. (2005). Extinction order and altered community structure rapidly disrupt ecosystem functioning. Ecology Letters, 8(5), 538-547. https://doi. org/10.1111/j.1461-0248.2005.00749.x

Laurance, W. F., Goosem, M., \& Laurance, S. G. (2009). Impacts of roads and linear clearings on tropical forests. Trends in Ecology and Evolution, 24(12), 659-669. https://doi.org/10.1016/j.tree.2009.06.009

Lindshield, S. M. (2016). Protecting nonhuman primates in peri-urban environments: A case study of neotropical monkeys, corridor ecology, and coastal economy in the Caribe Sur of Costa Rica. In M. T. Waller (Ed.), Ethnoprimatology: Primate Conservation in the 21st Century (Developments in Primatology: Progress and Prospects) (pp. 351369). Springer International Publishing. https://doi. org/10.1007/978-3-319-30469-4

Lokschin, L. X., Printes, R. C., Cabral, J. N., \& Buss, G. (2007). Power lines and howler monkey conservation in Porto Alegre, Rio Grande Do Sul, Brazil. Neotropical Primates, 14(2), 76-80. https://doi. org/10.1896/044.014.0206

Memmott, J., Waser, N. M., \& Price, M. V. (2004). Tolerance of pollination networks to species. Proceedings of the Royal Society Series B: Biological Sciences, 271(1557), 2605-2611. https://doi.org/10.1098/ rspb.2004.2909

Monge-Nájera, J. (2018). Road kills in tropical ecosystems: a review with recommendations for mitigation and for new research. Revista de Biología Tropical, 66(2), 722-738. https://doi.org/10.15517/RBT.V66I2.33404 
Moore, R. S., Nekaris, K. A. I., \& Eschmann, C. (2010). Habitat use by western purple-faced langurs Trachypithecus vetulus nestor (Colobinae) in a fragmented suburban landscape. Endangered Species Research, 12(3), 227-234. https://doi.org/10.3354/esr00307

Ram, C., Sharma, G., \& Rajpurohit, L. S. (2015). Mortality and threats to Hanuman langurs Semnopithecus entellus entellus in and around Jodhpur (Rajasthan). Indian Forester, 141(10), 1042-1045.

Rodrigues, N. N., \& Martinez, R. A. (2014). Wildlife in our backyard: interactions between Wied's marmoset Callithrix kuhlii (Primates: Callithrichidae) and residents of Ilhéus, Bahia, Brazil. Wildlife Biology, 20(2), 91-96. https://doi.org/10.2981/wlb.13057

Rybicki, J., \& Hanski, I. (2013). Species-area relationships and extinctions caused by habitat loss and fragmentation. Ecology Letters, 16(1), 27-38. https://doi. org/10.1111/ele.12065

Saavedra-Rodríguez, C. A., Lizcano, A., \& Corrales, J. D. (2013). Incidentes de fauna silvestre en líneas de energía en zona rural del Valle del Cauca, Colombia. Revista Biodiversidad Neotropical, 3(2), 85-89. https://doi.org/10.18636/bioneotropical.v3i2.102.g95

Spellerberg, I. F. (1998). Ecological effects of roads and traffic: a literature review. Global Ecology and Biogeography Letters, 7(5), 317-333. https://doi. org/10.1046/j.1466-822x.1998.00308.x
Teixeira, F. Z., Printes, R. C., Fagundes, J. C. G., Alonso, A. C., \& Kindel, A. (2013). Canopy bridges as road overpasses for wildlife in urban fragmented landscapes. Biota Neotropica, 13(1), 117-123. https://doi. org/10.1590/S1676-06032013000100013

Turner, I. M. (1996). Species loss in fragments of tropical rain forest: a review of the evidence. Journal of Applied Ecology, 33(2), 200-209. https://doi. org/10.2307/2404743

van der Ree, R., Jaeger, J. A., van der Grift, E. A., \& Clevenger, A. P. (2011). Effects of roads and traffic on wildlife populations and landscape function: Road ecology is moving toward larger scales. Ecology and Society, 16(1), 48-58. https://doi.org/10.5751/ ES-03982-160148

Van Wieren, S. E., \& Worm, P. B. (2001). The use of a motorway wildlife overpass by large mammals. Netherlands Journal of Zoology, 51(1), 97-105. https://doi.org/10.1163/156854201X00071

Weston, N., \& Goosem, M. (2011). Using canopy bridges to link habitat for arboreal mammals: successful trials in the wet tropics of Queensland. Australian Mammology, 33(1), 93-105. https://doi.org/10.1071/ AM11003

Yokochi, K., \& Bencini, R. (2015). A remarkably quick habituation and high use of a rope bridge by an endangered marsupial, the western ringtail possum. Nature Conservation, 11, 79-94. https://doi. org/10.3897/natureconservation.11.4385 